\title{
Correction to: A comparison of isomaltulose versus maltodextrin ingestion during soccer-specific exercise
}

\author{
Emma J. Stevenson ${ }^{1} \cdot$ Anthony Watson $^{2} \cdot$ Stephan Theis $^{3} \cdot$ Anja Holz $^{3} \cdot$ Liam D. Harper $^{4} \cdot$ Mark Russell $^{5}$ (I)
}

Published online: 16 November 2017

(c) The Author(s) 2017. This article is an open access publication

\section{Correction to: Eur J Appl Physiol (2017) 117:2321-2333 https://doi.org/10.1007/s00421-017-3719-5}

The article "A comparison of isomaltulose versus maltodextrin ingestion during soccer-specific exercise", written by "Emma J. Stevenson, Anthony Watson, Stephan Theis, Anja Holz, Liam D. Harper, Mark Russell", was originally published Online First without open access. After publication in volume [117], issue [11], page [2321-2333] the author decided to opt for Open Choice and to make the article an open access publication. Therefore, the copyright of the article has been changed to (C) The Author(s) [2017] and the article is forthwith distributed under the terms of the Creative Commons Attribution 4.0 International License (http:// creativecommons.org/licenses/by/4.0/), which permits use, duplication, adaptation, distribution and reproduction in any medium or format, as long as you give appropriate credit to the original author(s) and the source, provide a link to the Creative Commons license, and indicate if changes were made. The original article was corrected.

Open Access This article is distributed under the terms of the Creative Commons Attribution 4.0 International License (http://creativecommons.org/licenses/by/4.0/), which permits unrestricted use, distribution, and reproduction in any medium, provided you give appropriate credit to the original author(s) and the source, provide a link to the Creative Commons license, and indicate if changes were made.
The original article can be found online at https://doi. org/10.1007/s00421-017-3719-5.

Mark Russell

m.russell@leedstrinity.ac.uk

1 Institute of Cellular Medicine, Newcastle University, Newcastle upon Tyne, UK

2 Human Nutrition Research Centre, School of Agriculture, Food and Rural Development, Newcastle University, Newcastle upon Tyne, UK

3 BENEO-Institute, Obrigheim/Pfalz, Wormserstrasse 11, Obrigheim 67283, Germany

4 Human and Health Sciences, University of Huddersfield, Huddersfield, UK

5 School of Social and Health Sciences, Leeds Trinity University, Leeds LS18 5HD, UK 